\title{
Brakyterapi av malignt melanom i øyet
}
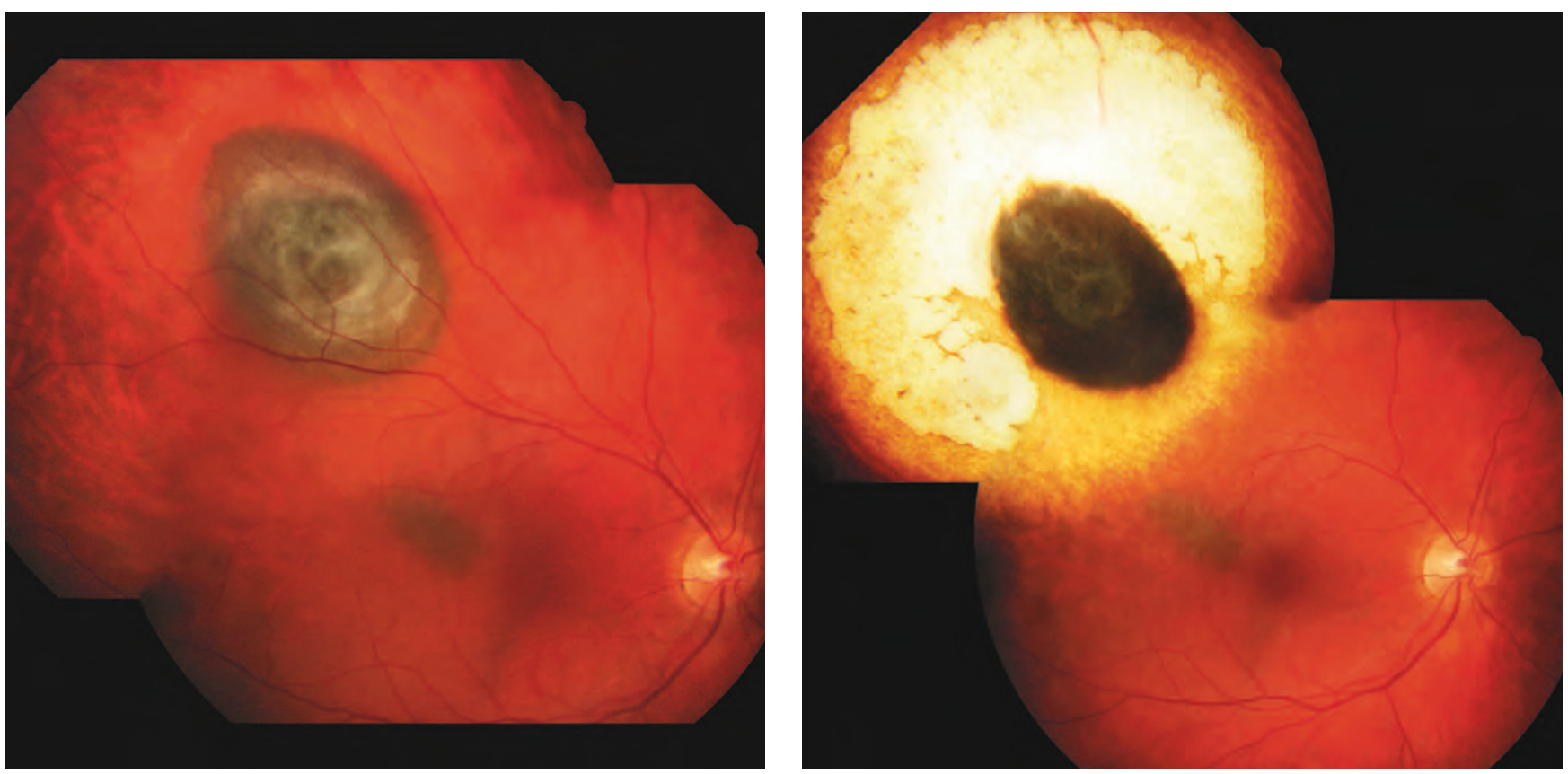

En tidligere frisk kvinne i 20-årene merket gradvis synsreduksjon og en skygge i synsfeltet til høyre øye. Ved oftalmoskopi ble det påvist et koroidalt malignt melanom oppad temporalt for macula (bildet til venstre). MRog ultralydundersøkelse av øyet viste at melanomet hadde en størrelse på $8 \times 10 \mathrm{~mm}$ og en tykkelse på $3 \mathrm{~mm}$. Det var subretinalvæske omkring tumor og i macularegionen, og visus ble målt til 0,4.

Generell malignitetsutredning var negativ, og kvinnen ble operert med episkleral brakyterapi. En sirkulær sølvplate med radioaktivt ruthenium (diameter $15 \mathrm{~mm}$ ) ble suturert utenpå sclera, svarende til svulstens lokalisasjon i øyet. Etter tre dager ble platen fjernet. I løpet av få måneder var subretinalvæsken resorbert og visus bedret til 0,8 .

To år etter behandlingen var synsstyrken fortsatt 0,8 . Oftalmoskopi viste at det var blitt stråleindusert atrofi av tumor og vevet omkring (bildet til høyre). Den sirkulære atrofiske sonen rundt tumor tilsvarte området hvor rutheniumplaten var plassert. Platen ble desentrert $\mathrm{i}$ forhold til tumor for å unngå stråleskade av macula og synsnerve.

Uvealt melanom er den hyppigste primære maligne øyesvulst hos voksne, med en forekomst på 40-50 nye tilfeller i Norge per år. De fleste pasientene kan behandles med episkleral brakyterapi. Hvis tumor går i regress med atrofi av omkringliggende vev, anses de som helbredet for selve øyesvulsten. De må likevel gå til jevnlig kontroll i flere år for å se at det ikke oppstår strålerelaterte komplikasjoner, residiv eller metastaser. Hvis svulsten er for stor eller innbefatter synsnerven, kan det være nødvendig å fjerne øyet $(1,2)$.

Pasienten har gitt samtykke til at artikkelen blir publisert.

\section{Jørgen Krohn}

jorgen.krohn@helse-bergen.no

Øyeavdelingen

\section{Olav Dahl}

Tone Nybø

Avdeling for kreftbehandling og medisinsk fysikk

\section{Bård Kjersem}

Øyeavdelingen

Haukeland universitetssykehus

Jørgen Krohn (f. 1959) er spesialist i øyesykdommer, overlege og professor ved Klinisk institutt 1, Universitetet i Bergen.

Forfatter har fylt ut ICMJE-skjemaet og oppgir ingen interessekonflikter.
Olav Dahl (f. 1948) er spesialist i onkologi, overlege og professor ved Klinisk institutt 2, Universitetet i Bergen.

Forfatter har fylt ut ICMJE-skjemaet og oppgir ingen interessekonflikter.

Tone Nybø (f. 1974) er medisinsk fysiker. Forfatter har fylt ut ICMJE-skjemaet og oppgir ingen interessekonflikter.

Bård Kjersem (f. 1955) er fotografmester og medisinsk fotograf.

Forfatter har fylt ut ICMJE-skjemaet og oppgir ingen interessekonflikter.

\section{Litteratur \\ 1. Krohn J, Monge OR, Skorpen TN et al. Posterior uveal melanoma treated with $\mathrm{I}-125$ brachytherapy or primary enucleation. Eye (Lond) 2008; 22: $1398-403$. \\ 2. Kreft i auget og strålebehandling - Helse Bergen www.helse-bergen.no/kreftiauget (1.11.2013).}

Mottatt 24.9. 2013, første revisjon innsendt 2.11. 2013, godkjent 7.11. 2013. Redaktør: Matilde Risopatron Berg. 